\title{
Students' Emotive Reaction and Confidence in Doing Language Tests: A Case of Test Takers in EFL Learning in Indonesia
}

\author{
Abdul Kamaruddin \\ Department of English Education, Tadulako University, Palu, Indonesia \\ Konder Manurung \\ Department of English Education, Tadulako University, Palu, Indonesia
}

\begin{abstract}
It has long been argued that the tests administered to students influence the students' learning motivation. The study aims at investigating the students' emotive reactions and confidence in doing English language tests and its implications for EFL learning. Forty-two students of the Department of English Education, University of Tadulako, Palu, Indonesia participated in the research. The students were programming Speaking Class in the Academic Year 2016/2017. Questionnaire items and focused group discussions were employed to produce the data needed. From the data analysis, it reveals that the use of language tests motivates the students in learning English despite the stressful situations they experience while they are sitting on the tests. Interestingly, the research findings show that the students are delightful in doing the tests. The students are most confident in speaking tests, but they are least confident in writing tests. Reading tests are in second place in terms of the student confidence in doing tests and listening tests are in the third place. How language testing motivates EFL learners is discussed.
\end{abstract}

Index Terms - emotive reaction, confidence, language test, test takers, EFL learner

\section{INTRODUCTION}

Language tests, nowadays, are used for different purposes such as teaching and learning packages, job recruitment, university admission, and screening for visa applications. In the case of teaching and learning packages, the application of information derived from tests affects the curriculum and syllabus design, as well as the development of teaching materials, which, in turn, affect the process of learning the language. Testing and evaluation are two terms that have long been used interchangeably to measure learners achievement in language learning. The former is commonly related to learners' attainment of the formulated instructional objectives while the latter is related to both learners' achievement and the results of the conduct of a language program. The results of testing and evaluation in language learning are used to categorize whether a learner is successful or fail in language learning and whether or not a language program needs improvement. In relation to the language program, the results of testing and evaluation are used to revitalized or develop the language curriculum.

The use of language tests in the classroom aims at assessing the students' progress after a certain period of teaching and learning. Tests are also administered to the students in order to make decisions as to whether they are qualified to progress to a higher level of the course. More importantly, the tests and the tests' results are used to get feedback on both the instructional materials and the instructional program. Due to the vital role of the tests and the tests' results, test designers must avoid "misconception about the development of and use of language tests, and unrealistic expectations about what the tests can do and what they should like" (Bachman \& Palmer, 1996, p.3). However, even though the language tests have been designed accordingly, it is frequently observed that most Indonesian EFL learners who sit the EFL tests seem stressful. This paper, therefore, is to ascertain whether or not the application of tests affects the Indonesia EFL learners, and if it does, how these effects are manifested.

Language testing is considered as one of the vital instruments that can describe whether or not a learner is successful or fail in language teaching and learning. Due to the vital role of the language testing, it is important to ensure that the development and the use of the language testing be familiar to language teachers. Bachman \& Palmer (1996) highlighted that ability to identify characteristics of learners facilitates test takers' performance. The characteristics include language ability, topical knowledge, or knowledge schemata, and affective schemata (Bachman \& Palmer, 1996, p.12). Some researchers (Chastain, 1975; Ghasemali \& Reza, 2013; Hughes, 2003; Javed, Juan, \& Nazli, 2013; Lee, 2007; Scovell, 1978; Shohamy, 1985; Xiao \& Carles, 2013) have investigated the effects of testing on teaching and learning and they reported that testing can be contributed either positive or negative effect on language learners performance.

Besides the effect of test on language learner performance, researchers also attempt to integrate language testing and the student perception. In order to attain the expected effect of the testing and the assessment on language teaching and 
learning, EFL teachers implement and select appropriate method on the administration of the language testing and assessment (Birjandi \& Tamjid, 2012; Cheng, Rogers, \& Hu, 2004; Jabbarifar \& Elhambakhsh, 2012; Zhao (2014). These researchers report that when testing is integrated to teaching and learning process the test underpins the attainment of the instructional objectives. More importantly, Birjandi \& Tamjid (2012) and Zhao (2014) insist that EFL teachers support on assessment affects learners' perceptions. It is reported that learners' achievement in language testing is better when teachers know their students better (Bachman \& Palmer (1996). In addition, Hughes (2003) and Jabbarifar \& Elhambakhsh (2012) argued that the tests have positive effects on teaching and learning when they are administered based on needs analysis of the course level the students are taking and it is the role of the language teachers to do the needs analysis. This is in line with Waterworths (2016) argument that a good quality English language program assists learners to increase their knowledge.

Testing may affect students' perceptions of tests in terms of learning motivation, attitudes to tests and emotive reaction when doing tests. Students' emotive reactions refer to their feelings and emotion in doing language tests. Some researchers (Bachman \& Palmer, 1996; Cohen, 2001; Hughes, 2003; Jabbarifar \& Elhambakhsh, 2012) have investigated the effect of the test on learners' emotive reaction. Bachman \& Palmer (1996, p.31) view the effect of the test based on the testing procedure include "the experience of taking, and preparing for the test, the feedback they receive, and the decisions that may be made about them on the basis of their test scores". Cohen (2001) explains that teachers and students may feel uncomfortable when they hear the word 'testing'. The students consider tests will threaten their language proficiency as they are afraid of not doing well in the tests. In addition, Hughes (2003) and Jabbarifar \& Elhambakhsh (2012) admit that tests may have positive effects on teaching and learning when they are administered based on an analysis of the English needs of the course level the students are taking. The tests should directly assess the skills needed and should be in accordance with the students' language proficiency levels. Tests may motivate students to study as they would like to be successful.

Since the language tests have proven their potential contribution and role on development and improvement of language teaching and learning, the language tests have also been implemented to measure language achievement and to improve language teaching and learning process in the four language skills. In order to achieve its purpose, the test must meet six test qualities include quality, reliability, construct validity, authenticity, interactiveness, impact, and practicality (Bachman \& Palmer, 1996, p.17). Most researchers have implemented the six test qualities in various language test types to measure the language skills, however, the reports were mostly on the performance or proficiency level in the four language skills. For example, Barekat \& Nobakhti (2014), LaClare, Roger, \& Rowberry (2014), and Leveridge \& Yang (2013), reported results of language tests in listening skills; Grubor (2013), Haizhen \& Fangqi (2015), and Manurung (2015) reported results of language tests in speaking skills; Katalayi, \& Sivasubramaniam (2013), Kim, Petscher, \& Foorman (2015), and Yaghoub, Farnia, \& Geva (2012) reported results of language tests in reading skills; and Javed, Juan, \& Nazli (2013) and Lovett, Lewandowski, \& Gathje (2010) reported results of language tests in writing skills. The results of language tests have also been used in language learning in self-assessment and self-access center (Engelhardt and Pfingsthorn, 2012; Manurung, 2002; Manurung, 2005;). Quite a few if it is none researchers, at least in Indonesian research results, report test taker' emotive reaction and confidence in doing tests on the four language skills. The present study, therefore, aims at, first, investigating EFL learners' emotive reaction in doing a test, second, comparing students' confidence in doing tests on the four language skills.

\section{THE RESEARCH METHOD}

The study was conducted at the English Education Department at Tadulako University, Palu, Indonesia. The setting for the research was chosen because it provides English course for foreign language learners, and the levels of courses vary from elementary to advance. Another reason for the selection of the research setting was that teaching materials were regularly evaluated and developed. Finally, the research was conducted at the English Education Department because it was easily accessible by the researcher.

Data were collected from 42 students attending speaking II class. In collecting the data, the researcher employed questionnaire and focus group discussions. The purpose was to obtain information about students' perceptions of the effect of testing on students' emotive reaction and confidence in doing English tests on language skills. The focus group discussions were conducted to obtain general information about the effects of testing on student learning activities and achievement. The question that was asked of students in the focus group discussion were largely unstructured, which gave respondents the opportunity to answer the questions freely but in relation to the topic being asked. The unstructured interview items can provide a width of interpretations and responses across the respondents (Wiersma and Jurs, 2005).

The target population of the research was the cohort of students who were taking speaking II. This course level was chosen because the students had done tests on a number of occasions, and it was reasonable to expect that their learning activities and achievements may have been affected by administration of tests. It was also reasonable that students studying at the second semester in the university would provide a variety of perceptions of the effects of testing on their emotive reactions and confidence in doing English tests.

Fifty copies of the questionnaire were distributed to students. The students may decide to join the survey or not. Of the fifty questionnaires distributed, forty-two copies were returned. For practical reasons, the forty-two students who 
responded to the questionnaires were regarded as a working sample of the population. The sample size was regarded as being a minimum from which trends and generalizations could be identified. The number of students enrolled in English Education Study Program in 2015 was 127. This suggests that a cohort of forty-two students willing to give time to this study would be a realistic sample size.

\section{Instruments}

\section{Questionnaire}

The copies of the questionnaire were distributed to students after class time in order not to interfere with the teaching and learning process and took approximately ten minutes for the students to answer. The students completed the questionnaires in the classroom or outside the classroom at the campus and returned the completed questionnaire to a box provided in the office of the English Education Department. This way of completing questionnaire was considered as anonymous because the participants did not need to identify themselves to the researcher. The students were assured that their responses would remain confidential and that only the researcher would have access to them.

The questionnaire consists of twelve questions employed to obtain information about whether the language tests done by the students had any effect on their learning activities and their English proficiency. The twelve questions administered to the research participants were viewed as a minimum to obtain consistent and valid information on the topic, while not over-extending students' concentration and thus introducing the extraneous variable of test fatigue. The questions were also produced in English, which was a foreign language for the respondents so the test could not be too long, otherwise the respondents may have difficulty understanding or translating the questions and this could become a variable. The questions were developed by the researcher and had been pilot-tested with a small group of the target population. Seven students participated in the pilot-testing of the questionnaire. The purpose of the pilot-test was to review the questionnaire items in order to identify misunderstandings or inadequate items. Wiersma and Jurs (2005) explain that a pilot-run of the items is intended to obtain information about confusion and ambiguous language, and can also be useful in obtaining preliminary information about possible patterns of result from the research. The result of the pilot-testing showed that students could do question 1 through 11 . However 4 students did not do question 12 in the pilot study because the question required the students to describe the effects of test on their use of language in the written context. As this required a degree of introspection and meta-cognition, some students clearly found it to be difficult. Thus it was modified for the final version of the questionnaire in order that the students easily understood it and gave short answers.

In completing questions 1 to 11 of the questionnaire, the respondents had six options to choose from, and the questionnaire items were scored on a six-point Likert scale: strongly agree-5, agree-4, tend to agree-3, tend to disagree2 , disagree-1, and strongly disagree- 0 . There was no neutral option on the questionnaire because all of the participants were directly involved in the process of second language learning and it could reasonably be assumed that the process was central to their daily lives. Consequently, a neutral response might be functional. In question 5, the respondents gave information about their emotive reaction by selecting six options indicating the notion of happiness in doing tests; very happy - 5 , happy - 4 , tend to be happy - 3, tend to be unhappy - 2, unhappy - 1 and strongly unhappy - 0 .

\section{Focus Group Discussion}

Consent forms for the group discussion were distributed along with the questionnaires to students, but only ten students completed and returned the form. The ten students who consented to participate in a focus group discussion were questioned to gain their general responses about the effects of tests on the process and outcomes of the EFL learning. Those ten students were split into two groups, and one single interview. Groups one and two consisted of five and four students, respectively. The students were split into small groups in order that they had sufficient opportunities to speak during the discussions. The single interview was conducted because one student missed the group discussions. The focus group discussions and interview were audio-taped and transcribed for further data analysis.

\section{Data analysis}

Data were analyzed statistically to investigate the possible relationship between student attitude to language tests and their selection of strategies in acquiring the target language. The data obtained from the questionnaire were tabulated using the SPSS software program to find out the percentage of the students' responses to each option of the questionnaire items (see Tables 1 and 3), and the correlation between one item and the others (see Tables 2 and 4). The analysis also specifically looked at the Mean Scores of the students' confidence in different language skills (Table 5).

The result or the focus group discussion was analyzed descriptively. The analysis was included in the result of the research to support the data from the questionnaire. The analysis was also generally compared to the result of the questionnaire. The comparison of the two sources of data was done to cross-check the students' individual responses to questions against the students' group perceptions of the effects of tests on EFL learning.

Overall, it was expected that the direct, objective reactions obtained from the questionnaire would be expanded and clarified by the less formal, more detailed explanations given during the qualitative responses in the discussions. This balanced research method was employed in order to provide data-driven interpretation of the questionnaire material, rather than relying solely on the intuition of the researcher.

\section{FINDINGS AND DISCUSSION}

\section{Students' emotive reaction in doing tests}


Most of the students involved in the project responded positively to the effects of tests on language learning by choosing the positive options on the questionnaire (e.g. strongly agree, agree and tend to agree). Tests administered to students had apparently influenced the students' learning motivation (Lambert \& Gardner, 1972).

TABLE I.

THE EFFECTS OF TESTS ON LANGUAGE LEARNING

\begin{tabular}{|c|c|c|c|c|c|}
\hline \multirow{8}{*}{ Valid } & & Frequency & Percent & Valid Percent & Cumulative Percent \\
\hline & Strongly disagree & 0 & 0.0 & 0.0 & 0.0 \\
\hline & Disagree & 2 & 4.8 & 4.8 & 4.8 \\
\hline & Tend to disagree & 1 & 2.4 & 2.4 & 7.1 \\
\hline & Tend to agree & 12 & 28.6 & 28.6 & 35.7 \\
\hline & Agree & 12 & 28.6 & 28.6 & 64.3 \\
\hline & Strongly agree & 15 & 35.7 & 35.7 & 100.0 \\
\hline & Total & 42 & 100.0 & 100.0 & \\
\hline
\end{tabular}

The data in Table 2 shows that the students responded differently to their state of feeling when doing tests. There were more students (61 percent) who responded that they were happy when doing tests; 11.9 percent of them responded 'very happy', 21.4 percent responded 'happy' and 26.2 percent responded 'tend to be happy'. However, 39 percent of the students responded negatively to doing tests, in which 7.1 percent chose the unhappy option, 31.0 percent responded 'tend to be unhappy' but interestingly no one responded 'very unhappy'. One student did not respond to the question.

TABLE II

THE STATE OF FEELING WHEN DOING TESTS

\begin{tabular}{llllll}
\hline & & Frequency & Percent & Valid Percent & Cumulative Percent \\
\hline Valid & Very happy & 5 & 11.9 & 12.2 & 12.2 \\
& Happy & 9 & 21.4 & 22.0 & 34.1 \\
& Tend to be happy & 11 & 26.2 & 26.8 & 61.0 \\
& Tend to be unhappy & 13 & 31.0 & 31.7 & 92.7 \\
& Unhappy & 3 & 7.1 & 7.3 & 100.0 \\
& Very unhappy & 0 & 0.0 & 0.0 & 100.0 \\
& Total & 41 & 97.6 & 100.0 & \\
Missing & System & 1 & 2.4 & & \\
Total & & 42 & 100.0 & & \\
\hline
\end{tabular}

The Students who were happy when doing tests were also motivated to study, as shown in Table 3. Information from this table indicates the correlation between the student happiness in doing tests and other questions of the survey. The most important information obtained from the table is that the happier the students, the more motivated they are in learning the lessons of the course. Table 3 also shows that the students' happiness in doing tests and their learning motivation are significantly correlated (at 001).

TABLE III.

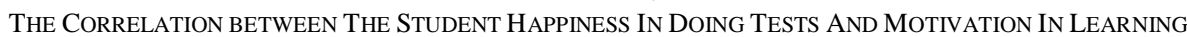

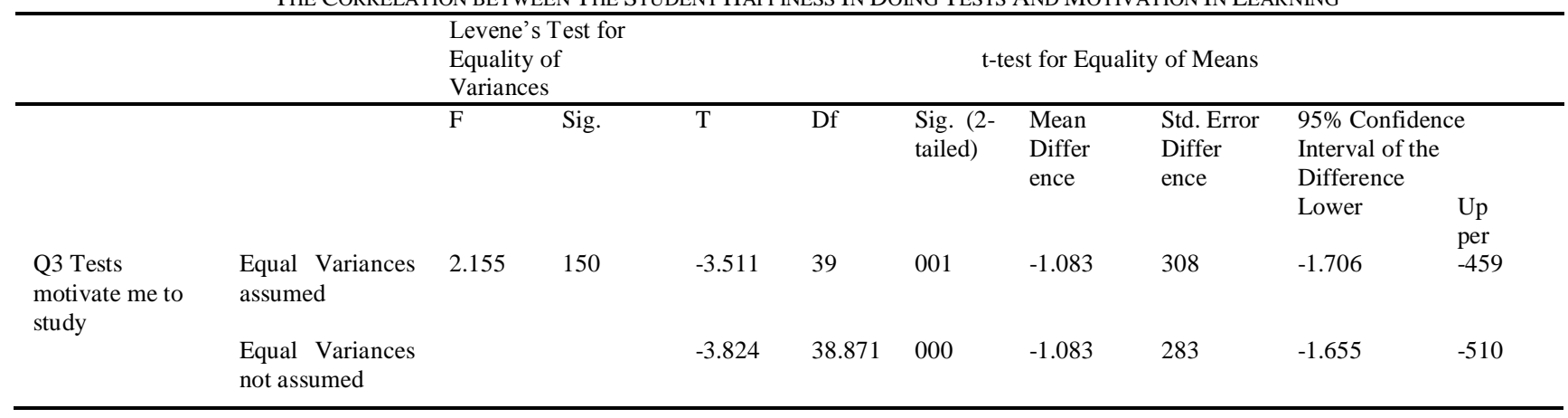

However, students also experienced stress when doing tests. The results of the survey showed that the majority of students experienced stress when doing formal language tests. This can be seen from Table 4 where 85.7 percent of the students selected the positive options, from which 50 percent responded agree, 19 percent responded strongly agree, and 16.7 percent responded tend to agree. However, 14.3 percent of the students chose the negative options, from which 9.5 percent of the students responded that they did not experience stress when doing formal language tests, and 2.4 percent responded that they tended to disagree that they experienced stress when doing tests. Another 2.4 percent of the students responded that they never became stressed because of tests, as this student chose the strongly disagree option. 
TABLE IV.

THE STUDENTS' EXPERIENCE WHEN DOING TESTS

\begin{tabular}{|c|c|c|c|c|c|}
\hline & & Frequency & Percent & Valid Percent & Cumulative Percent \\
\hline \multirow[t]{7}{*}{ Valid } & Strongly disagree & 1 & 2.4 & 2.4 & 2.4 \\
\hline & Disagree & 4 & 9.5 & 9.5 & 11.9 \\
\hline & Tend to disagree & 1 & 2.4 & 2.4 & 14.3 \\
\hline & Tend to agree & 7 & 16.7 & 16.7 & 31.0 \\
\hline & Agree & 21 & 50.0 & 50.0 & 81.0 \\
\hline & Strongly agree & 8 & 19.0 & 19.0 & 100.0 \\
\hline & Total & 42 & 100.0 & 100.0 & \\
\hline
\end{tabular}

\section{Student confidence in doing tests on the four language skills}

Students had different levels of confidence in doing tests on the four language skills: listening, speaking, reading and writing. Students were more confident doing tests on speaking (Mean 3.07), followed by reading (Mean 2.93). Listening tests were third in terms of the students' confidence in doing them (Mean 2.67), and students were least confident in doing tests on writing (Mean 2.57).

The data in Table 5 shows that students who were confident doing tests on listening were also confident doing tests on speaking, reading, and writing. Also, students who were confident in doing tests on speaking were confident in reading and listening, and those students who were confident in reading tests were also confident in writing tests. However, students who were confident in speaking tests were not necessarily confident in writing tests.

TABLE V.

PAIRED SAMPLES CORRELATIONS OF STUdENTS' CONFIDENCE IN DOING TESTS ON LANGUAGE SKILLS

\begin{tabular}{llccc}
\hline & Description & Correlation & Sig. \\
\hline Pair 1 & I'm confident in doing tests on listening \& I'm confident in doing tests on speaking & 42 & 489 & \\
Pair 2 & I'm confident in doing tests on listening \& I'm confident in doing tests on reading & 42 & 344 & 001 \\
Pair 3 & I'm confident in doing tests on listening \& I'm confident in doing tests in writing & 42 & 337 & 026 \\
Pair 4 & I'm confident in doing tests on speaking \& I'm confident in doing tests on reading & 42 & 323 & 029 \\
Pair 5 & I'm confident in doing tests on speaking \& I'm confident in doing tests in writing & 42 & 177 & 037 \\
Pair 6 & I'm confident in doing tests on reading \& I'm confident in doing tests in writing & 42 & 493 & 263 \\
\hline
\end{tabular}

Tests can possibly motivate students to study. The time frame and the structure of a language course can encourage the students to prepare themselves for tests in order to achieve high scores and move to the next levels. Social and family pressure is another aspect that encourages the students to succeed in their English studies. In this situation, the students must learn lessons intensively in order to be able to better perform the tests and meet the requirements for the completion of their studies from the university.

Language tests may have a positive or negative influence on students' motivation to learn the target language. Students may respond differently to the effect of tests on their motivation in the learning process (McNamara, 2001; Hughes, 2003). This happens because the students may have different perceptions about tests. Students who participated in the research had mixed feelings when doing tests. As shown in Table 2, the majority of students (85.7 percent) experienced stress in relation to tests. Interestingly, a high proportion of students were also 'happy' when tests were administered to them. Table 4 describes that 61 percent of the students responded that they were happy to undertake the tests, while only 39 percent of them responded negatively. The students were under stress but they were also 'happy' because testing was a part of the process of the language studies. Clearly, they became much happier when they passed the tests and moved to the next level of the course.

However, the inclusion of testing procedures has often been looked on with mixed feelings by language teachers, since it is possible for stress and anxiety to have severe detrimental effects on student language. The result of this questionnaire appears to indicate that the majority of students accept that such stress is a normal part of learning and would much rather have tests included in their course, rather than excluded.

The results of the focus group discussions show that some of the students were very anxious to be able to complete their language studies. They had a high expectation of passing the language tests. Therefore, they studied the target language extensively in order to obtain perform well in the tests. Those students intended to complete their undergraduate degree in three and a half years.

There is a significant correlation at 001 (Table 3) between the students' happiness in doing tests and the learning motivation. This indicates that the happier the students were the more motivated they were in studying the target language. Teachers are thus encouraged to provide interesting and enjoyable learning materials and learning activities in order for the students to become positively motivated. If the students find the materials interesting, they are more likely to be happy and be motivated in the process of learning, and as a result, the student learning achievement may be improved. Although the results of tests in such courses may be viewed as having serious consequences for student career advancement, it seems clear that some levity, comfort, and easing of pressure is likely to prove productive for many such learners.

Interestingly, the student stress level was also significantly correlated with their learning motivation at .030 (Table 5), which means that the more stressed the students were the more motivated they were in their studies. This indicates that stress does not always have a negative effect on student learning but that it may also stimulate learning motivation. 
Clearly, teachers need to be aware of possible dual effects of stress on students and try to maintain a productive stress level rather than a debilitating one. The findings of Chastain (1975) and Scovell (1978) are of importance in developing this realization.

Student confidence in doing tests was another factor investigated in this research. The results of the survey suggest that the students had different levels of confidence in doing tests across language skills that include listening, speaking, reading and writing. The students were most confident in speaking test but they were least confident in writing tests.

Speaking and writing are productive skills which require the students to do an extensive amount of practice in order to be able to better perform in the tests. The students may have different reasons for performing more confidently in speaking tests. As the information obtained from the focus group discussions indicates, the students had more opportunities to practice using the target language in the classrooms with their teachers or classmates and outside the classrooms with other users of the target language. Another reason is that students may experience less psychological pressure when doing speaking tests, as they can freely express their ideas which are related to the topic being discussed in the tests. Besides, spoken language can be perceived to lack substance an utterance can be changed or recanted quite quickly.

However, in writing tests, the students have to display a number of different skills at the same time. They are expected to be knowledgeable in writing well-structured paragraphs. They also have to possess sufficient knowledge of grammar and sufficient vocabulary in order to be able to produce different kinds of sentences to express their ideas in written contexts. Writing, too, is a more tangible; concrete piece of evidence of language skill whereas spoken language is transient and may be modified during production. Thus, the degree of accountability and responsibility for written text can be viewed to be heavier than that for spoken one. It is thus the substantial nature and judgmental attitudes on spelling, grammar, etc. that can cause a loss of confidence in relation to written formats.

Reading tests are in second place in terms of the students' confidence in doing tests of language skills, followed by tests on listening skills. The students were not highly confident in doing tests on listening and reading. Listening and reading skills are receptive skills which may require the students to possess the ability to receive and understand a variety of language used in different contexts. In doing listening and reading tests, the students may have less opportunity to produce the language but they have to be able to comprehend a range of varieties of spoken and written language. Since the end-product of these receptive skills is the social understanding achieved through communication, it becomes immediately and embarrassingly obvious if one does not achieve this understanding. One's basic social need to 'belong' to a group may well be impaired, so it is probably not surprising that such 'high stakes' activities may well be accompanied by some lack of confidence.

Celce-Murcia (2001) suggests that language skills and language components should be integrated into teaching in order the students can learn different skills simultaneously. This will also help the students to gain proficiency in those four language skills. The teacher has to provide teaching materials that enable the students to do exercises in different language skills. In the learning process, the teacher may emphasize one or two skills in order to be able to evaluate the students' progress in those emphasized skills during or after instruction. An appropriate aim for teachers may well be to try to instill the same confidence that characterizes speaking into the associated listening skill. Indeed, such integration is part of the foundation of the Communicative Approach to language learning and may be seen as being preferable to having the skills taught in isolation.

\section{CONCLUSION}

The administration of a test has both negative and positive effect on teaching and learning activities. Tests create student anxiety and stress in the process of learning. Nevertheless, the research findings also demonstrate that tests can motivate a majority of the students. Tests also benefit teachers since they provide information about the student learning progress or outcomes, the development of appropriate teaching materials and the selection of teaching methods.

Formal test administration tends to lead to students' stress and anxiety, and this tends also to lead to failure. The administration of tests, therefore, should minimize the students' stress and anxiety in order for the students to be motivated to prepare for tests and be relaxed during the tests. Thus, the students can perform better in the tests, as well as allowing the test itself to contribute positively to the students' language learning.

The tests provide a security blanket for students. Although tests produce stress and anxiety, the students are still encouraged to undertake the tests because tests are viewed as part of the integral structure of the language courses. The results of this research demonstrate a majority of the students (90 percent) respond that tests can motivate them to study the target language, because the tests become one of the processes of the language studies, the students are motivated to learn the target language extensively in order to improve language proficiency and expect to be able to perform well in the tests. The students are likely to be instrumentally motivated, because they learn the language in order to acquire proficiency and to succeed in the final semester tests. The students demonstrate different levels of confidence in terms of performing in tests across four language areas that include listening, speaking, reading and writing. Speaking tests are the most favored among the students and they are most confident in doing them. However, they are least confident in doing tests on writing. Reading tests are in second place in terms of the student confidence in undertaking tests, while listening tests are in third place. This description of the students' confidence in doing tests shows that the students have very different level of confidence in the tests of productive skills, while in the tests of receptive skills the student 
confidence is not significantly different. It implies that the teaching of the four language skills should not be in isolation at the beginning of a course but they must be paired as has been previously proposed by Celce-Murcia (2001) that the language skills and the language components are taught integratedly. The integration of the four language skills in language teaching learning process at the beginning of the course will accustom the learners with the test types used to assess their achievement, which in turn, from time to time, the known tests type will build up confidence of the learners to sit the language tests regardless of the type of the language skills. After getting a better confidence on any types of the language tests on language skill integratedly, the learners may be then tested in isolation based on taught language skills.

\section{REFERENCES}

[1] Bachman, L. F., \& Palmer, A.S. (1996). Language Testing in Practice: Designing and Developing Useful Language Test. Oxford: Oxford University Press.

[2] Barekat, B., \& Nobakhti, H. (2014). The effect of authentic and inauthentic materials in cultural awareness training on EFL learners"e listening comprehension ability, Theory and Practice in Language Studies, 4(5), 1058-1065.

[3] Birjandi, P. \&Tamjid, N. H. (2012). The role of self-, peer and teacher assessment in promoting Iranian EFL learners' writing performance. Assessment \& Evaluation in Higher Education, 37(5):513-533.

[4] Celce-Murcia, M. (2001) Teaching English as a Second or Foreign Language. Australia, New Zealand: Heinle \& Heinle.

[5] Chastain, K. (1975). Affective and ability factors in second language acquisition. Language Learning, 25, 153-161.

[6] Cheng, L., Rogers, T. and Hu, H. (2004). ESL/EFL instructors' classroom assessment practices: Purposes, methods, and procedures. Language Testing, 21(3), 360-389.

[7] Cohen, D. A. (2001). Second Language Assessment. In M. Celce Muria (Ed.). Teaching English as a Second or Foreign Language, pp 515-534. United States, Australia: Henle \& Heinle.

[8] Engelhardt, M., \& Pfingsthorn, J. (2012). Self-assessment and placement tests-a worthwhile combination? DE GRUYTER MOUTON, 2(1), 75-89.

[9] Ghasemali, A., \& Reza. G. (2013). Feedback of EFL test on ELT in L2 classroom. Theory and Practice in Language Studies, $3(8), 1335-1341$.

[10] Grubor, J. (2013). The construct of perceived L2 speaking proficiency in a paired testing format. Poznań Studies in Contemporary Linguistics, 49(2), 185-203.

[11] Haizhen, W., \& Fangqi, S. (2015). Effects of strategic planning time on L2 paired oral test performance. Chinese Journal of Applied Linguistics, 38(3), 263-278.

[12] Hughes, A. (2003). Testing for Language Teachers. Cambridge: Cambridge University Press.

[13] Jabbarifar, T., \& Elhambakhsh, E. (2012). The importance of examining teacher and learner`s attitudes and understanding learning needs in the twenty-first century. Journal of International Education Research, 8(2), 71-84.

[14] Javed, M., Juan, W. X., \& Nazli, S. (2013). A Study of Students' Assessment in Writing Skills of the English Language. International Journal of Instruction, 6 (2), 129-144.

[15] Katalayi, G. B., \& Sivasubramaniam, S. (2013). Careful reading versus expeditious reading: Investigating the construct validity of a multiple-choice reading test. Theory and Practice in Language Studies, 3(6), 877-884.

[16] Kim, Y., Petscher, Y., \& Foorman, B. (2015). The unique relation of silent reading fluency to end-of-year reading comprehension: Understanding individual differences at the student, classroom, school, and district levels. Reading and Writing, 28(1), 131-150.

[17] LaClare, E. J., Roger, A. E. M., \& Rowberry, J. W. N. (2014). Assessing the influence of test language on a test of listening comprehension. International Journal of Innovation in English Language Teaching, 3(2), 179-199.

[18] Lambert, W., \& Gardner, R. (1972). Attitudes and Motivation in Second Language Learning. Rowley, Mass: Newbury House.

[19] Lee, I. (2007). Assessment for learning: Integrating assessment, teaching, and learning in the ESL/EFL writing classroom. Canadian Modern Language Review, 64(1), 199-213.

[20] Leveridge, A., N., \& Yang, J., C. (2013). Testing learner reliance on caption supports in second language listening comprehension multimedia environments. ReCALL, 25(2), 199-214.

[21] Lovett, B. J., Lewandowski, L. J., Berger, C., \& Gathje, R. A. (2010). Effects of response mode and time allotment on college students' writing. Journal of College Reading and Learning, 40(2), 64-79.

[22] Manurung, K. (2015). Improving the speaking skill using reading contextual internet-based instructional materials in an EFL class in Indonesia. Procedia-Social and Behavioral Sciences, 176, 44-51.

[23] Manurung, K. (2005). Instructing language learning strategies to promote autonomous learning. Indonesian JELT, 1(2), 66-90.

[24] Manurung, K. (2002). Maximizing the Use of Language Learning Strategies in Self- Access Centres. La Trobe UniversityVictoria. Unpublished $\mathrm{Ph}$. D thesis.

[25] McNamara, T. (2001). Language Testing. Oxford: Oxford University Press.

[26] Scovell, T. (1978). The effect of affect on foreign language learning: A review of the anxiety research. Language Learning, 28, 129-142.

[27] Shohamy, E (1985). A Practical Handbook in Language Testing for the Second Language Teacher. Tel Aviv, Israel: School of Education.

[28] Waterworths, P. (2016). Teaching English in ASEAN: The voices of English Teachers in ASEAN nations. Indonesian Journal of Applied Linguistics, 5(2), 154-166.

[29] Wiersma, W., \& Jurs, G. S. (2005). Research Methods in Education. An Introduction. Boston, New York, Sydney: Pearson.

[30] Xiao, Y., \& Carles, D. R. (2013). Illustrating students' perceptions of English language assessment: Voices from China. RELC Journal, 3(2), 319-340.

[31] Yaghoub Z, Farnia, F., \& Geva, E. (2012). Toward modeling reading comprehension and reading fluency in English language 
learners. Reading and Writing, 25(1), 163-187.

[32] Zhao, H. (2014). Investigating teacher-supported peer assessment for EFL writing. ELT Journal, 68(2), 105-119.

Abdul Kamaruddin was born in Bolokut, 28 September 1974. He completed his Doctorate Degree in Education in 2014 at School of Education, LaTrobe University, Australia. He is a lecturer of English Language Teaching at the Department of English Education, Faculty of Teacher Training and Education, University of Tadulako, Palu Indonesia. His research interest includes TEFL/TESOL Pedagogy and Language testing.

Konder Manurung was born in Lumban Manurung, 19 August 1965. He earned his Doctorate Degree in Education in 2002 at School of Education, LaTrobe University, Australia. He is a lecturer of English Language Teaching at the Department of English Education, Faculty of Teacher Training and Education, University of Tadulako, Palu Indonesia. His research interest includes TEFL Methodology, Curriculum and Instructional Design, and Self-Access Materials Development. 